Celtic: A Journal of Culture, English Language Teaching, Literature and Linguistics

Vol. 7, No. 2, December 2020.

E-ISSN: 2621-9158 P-ISSN:2356-0401

http://ejournal.umm.ac.id/index.php/celtic/index

\title{
IMPROVING STUDENTS' SPEAKING ABILITY THROUGH DEBATE TECHNIQUE
}

\author{
${ }^{1}$ Reni Rosianna Lumbangaol*, ${ }^{1}$ Muhammad Rizki Mazali \\ ${ }^{1}$ Universitas Potensi Utama Medan, Indonesia \\ *Corresponding Author: reni.inparsaka@gmail.com
}

\begin{abstract}
Lecturers can use many strategies to improve speaking ability. Speaking abilities include making questions, providing explanations, and also being able to provide answers. This study aimed to determine how debate techniques can improve students' speaking ability to make questions, give explanations, and give responses. The current study applied the classroom action research method and consisted of 3 cycles. Two batches of English Education College Students of 2019/2020 at Universitas Potensi Utama, totaling 60 students, were involved as the study subjects. An observation checklist and field notes were used to collect the data. The researchers observed students' activity in the classroom by using an observation checklist and fieldnotes. The researchers summarized the problem during the debating process. Based on the research findings, the debate technique applied by the research subjects reflects the improvement in the students' speaking ability. Based on the observations' results, it can be seen that the students' speaking ability in making questions and providing explanations and answers improved. The students' activities in the class when arguing in the first cycle were $42.83 \%, 59.17 \%$ in the second cycle, and $85.17 \%$ in the final one. It shows that the debate technique has improved the students' speaking ability to make questions and provide explanations.
\end{abstract}

Keywords: Classroom Action Research; College Students; Debate Technique; Speaking Skill

\begin{abstract}
ABSTRAK
Dosen menggunakan banyak upaya dalam meningkatkan kemampuan berbicara. Kemampuan berbicara meliputi kemampuan dalam membuat pertanyaan, memberikan penjelasan, dan juga mampu memberikan jawaban dengan tepat. Penelitian ini bertujuan untuk mengetahui bagaimana teknik debat dapat meningkatkan kemampuan berbicara mahasiswa dalam membuat pertanyaan, memberikan penjelasan, dan juga jawaban dengan tepat. Penelitian ini menggunakan metode penelitian tindakan kelas yang terdiri dari 3 (tiga) siklus. Mahasiswa Pendidikan Bahasa Inggris 2 (dua) angkatan 2019/2020 di Universitas Potensi Utama yang berjumlah 60 mahasiswa dilibatkan sebagai subjek dalam penelitian ini. Dalam penelitian ini, peneliti mengumpulkan data dengan menggunakan observation checklist dan catatan lapang. Peneliti mengamati aktivitas siswa di dalam kelas dengan menggunakan observation checklist dan catatan lapang, peneliti merangkum masalah yang terjadi selama proses debat. Berdasarkan hasil penelitian yang telah dilakukan, teknik debat yang diterapkan pada subjek penelitian mencerminkan peningkatan kemampuan berbicara mahasiswa. Berdasarkan hasil observasi dengan menggunakan observation checklist dan lembar catatan lapang terlihat bahwa kemampuan berbicara mahasiswa dalam membuat pertanyaan dan memberikan penjelasan dan jawaban telah meningkat. Persentase keaktifan siswa di kelas saat berdebat pada siklus pertama adalah $42,83 \%, 59,17 \%$ untuk siklus kedua, dan $85,17 \%$ untuk yang terakhir. Hal tersebut menunjukkan bahwa teknik debat dapat meningkatkan kemampuan berbicara siswa dalam membuat soal dan memberikan penjelasan.
\end{abstract}


Kata Kunci: Keterampilan Berbicara; Mahasiswa; Penelitian Tindakan Kelas; Teknik Debat

\section{INTRODUCTION}

Speaking is a speech production that is part of our daily activities (Thornburry, 2005). The speaking skills can help students communicate their opinions, feelings, and expressions without being restricted in languages, cultures, and countries.

Mastering speaking skills are essential because people can start conversing with other people, delivering ideas, and exchanging information with others. People will be able to express feelings, convey meaning, give opinions, etc.

The failure or success of learning English depends on students' ability and readiness to participate in learning activities, influenced by their attitudes and interests towards English. The attitudes and interests of students can be created. They can be developed with the lecturer's innovations to attract attention and foster students' interest and motivation to learn. Ghazali (2013) explains that implementing "real communication" in the classroom can be determined by factors such as lesson objectives, students' skill levels, and types of role-playing activities, paired interviews, surveys/polls, or problem-solving situations.

Based on the researchers' observations, students cannot give opinions and respond to their friends' opinions in English. They cannot express their opinions to respond to other opinions, whether they agree or disagree with their friends' opinions. They were relatively silent when the lecturer asked them. It showed that they were passive, especially if the lecturer asks their opinions. They are afraid to express their opinions and respond because they do not know how to express their opinions or arguments in English. The students are fearful of making mistakes. Therefore, by applying debate as a teaching technique, it is hoped that students can give opinions and respond to other people's opinions appropriately.

One learning model that is expected to increase motivation and learning outcomes is to use the debate method. The debate method is one of the essential learning methods to improve English speaking skills. The debate is an activity to argue between two or more parties, both individually or in groups, discussing and deciding problems and differences (Mulyani, 2018).

Debate provides an opportunity to develop students' speaking skills. The debate can be a useful pedagogical technique because students are actively involved and responsible in the debate's learning process. By debating, students become more active in speaking and expressing their opinions or responses. The more students can express their opinions, the more likely they are to improve their speaking skills.

The process of conveying ideas or opinions that occur to two or more opposing parties and trying to defend their thoughts or opinions is called debate. The debate is usually used in an EFL classroom to get students to practice their speaking English skills. Here, the debate parts are as follows:

1. Motion is the debate topic.

2. Definition can be done in two ways; word by word definition or the global definition;

3. Theme line is the fundamental reason that answers the big question of why one side supports or opposes a motion;

4. Argument is a tool used by groups to defend their opinions or to oppose others' ideas; 
Celtic: A Journal of Culture, English Language Teaching, Literature and Linguistics

Vol. 7, No. 2, December 2020.

E-ISSN: 2621-9158 P-ISSN:2356-0401

http://ejournal.umm.ac.id/index.php/celtic/index

5. Rebuttal: There are two kinds of refutation. Global rebuttal: this is an attack on the opposing case's main core, the theme line. As a result, their case collapsed. Detailed rebuttal: this is an attack on every argument or example;

6. Sum-up/closing is simply concluding what has been through.

The debate will help students be more courageous in sharing ideas and develop their oral English skills. Through debate, students are expected to be more confident in conveying their views on various matters (Pradana, 2017). He added that a debatable topic could be a factor to motivate them to speak.

Debating can also develop some other skills to help students communicate effectively in English or whatever language the student speaks. In applying the debate method, several steps need to be considered, including:

1. The lecturer divides students into two groups of debate participants, one pro and the other contra,

2. The lecturer gives the assignment to read material that will be debated by the two groups,

3. The lecturer appoints one pro member to speak at the time, then the counter group responds. And so on until some students can express their opinions. While students convey their ideas, the lecturer writes ideas from each conversation until they get the expected number of ideas,

4. The lecturer adds concepts or ideas that have not been revealed,

5. From the data disclosed, the lecturer invites students to make conclusions or summaries that refer to the topics to be achieved,

6. The lecturer guides students to make conclusions according to the material discussed.

Debating is practiced in two groups (pros and cons) consisting of five students in each group. That way, students can convey opinions or ideas that are in their minds. It can help students improve their speaking skills by encouraging them. Iman (2017) claimed that debate could also significantly improve students' critical thinking and speaking skills.

The previous study investigating the implementation of Project-Based Learning (PBL) can improve students' speaking skills. By using PBL, students become more active and innovative in doing assignments and attending classes. The PBL approach is highly recommended in the speaking class as an alternative way to improve students' speaking competence (Mafruudloh \& Fitriati, 2020). Junaida and Prastiyowati (2018), in their research, revealed the results of CAR to prove that L1/L2 based strategies can improve speaking skills at class $\mathrm{X}$ students of Computer and Network Engineering Class C SMKN 4 Malang. Furthermore, Usman (2015) stated that the think-pair-share strategy was effectively applied to improve students' speaking ability.

Aristy, Hadiansyah, and Apsari (2019) revealed that the three-step interview technique increases students' speaking interest. The three-step interview technique can improve speaking skills in the classroom for the better. Fauzan (2014) found out that improvisation techniques can improve speaking skills among EFL students.

Speaking abilities are essential skills to produce the flow of articulation sound systems to convey the wants, needs, feelings, and desires to others (Iskandarwarsid, 2008). Lecturers have a significant role in motivating students to speak. A debate in the speaking session aims to improve students' critical thinking and communication skills. In debate activities, students have more opportunities to practice speaking. Iriantara and 
Syaripuddin (2013) argue that someone who can speak will be more comfortable to convey ideas or ideas to others, the success of using the idea so that it can be accepted by people who listen or are invited to talk. Conversely, someone who cannot speak will have difficulty in conveying ideas to others. Debates can force students to think about different sides of a problem and force students to interact with the details of a particular topic and with the details of a specific topic to one another (Krieger, 2005).

Regarding the facts above, there would be a tool to implement a new appropriate strategy to improve the students' speaking ability. The debate is a method to persuade the audience to become more interactive during the teaching-learning process. It engages students in a variety of meaningful listening and speaking.

This study answered whether there is a significant difference in speaking ability between students before and after experiencing debate techniques? This study aims to find answers to the problems formulated. Therefore, this study is to determine whether or not there is a significant difference in speaking ability between students before and after experiencing debate techniques.

\section{METHOD}

\section{Respondents}

The current study's participants were 24 female students and 36 male students of 2 (two) batches of English Education College Students of 2019/2020 academic year at Universitas Potensi Utama selected purposely due to the difference in the Speaking ability.

\section{Instruments}

There are two instruments used to collect data, namely observation sheets and field notes. The pre-test and post-test were applied to collect data.

\section{Procedures}

This research is using Classroom Action Research (CAR). Kunandar (2011) said that Classroom Action Research (CAR) is a study that aims to improve the quality of every lesson in class. This classroom action research can also bridge the gap between educational theory and practice. There are four stages of Classroom Action Research: planning, acting, observing, and reflecting.

\section{Data analysis}

The data analysis technique comes from the interpretation of data collection. In the data analysis, the researcher obtained data from the observation checklist and field notes about students' activities in class, observations of the teaching and learning process, and students' activities in the debate. In processing the data, researchers used descriptive analysis to explain the achievement of indicators in each cycle and describe the success of the teaching and learning process using debate in improving speaking skills.

In the observation checklist, ten aspects should be considered. These ten aspects are indicators of whether or not students take each step of the debate. The success indicators of this CAR project can be seen from the increase in the score of students being able to pay attention to researchers 'explanations, obey researchers' instructions, 
Celtic: A Journal of Culture, English Language Teaching, Literature and Linguistics Vol. 7, No. 2, December 2020.

provide opinions with expressions and hand gestures, provide clear opinions and appropriate statements, respond to other people's opinions and questions, and defend their opinions. These indicators will be assessed from the deficient category, which will be given a score of 1 , low which will be given a score of 2 , medium which will be given a score of 3 , high which will be given a score of 4 , and very high which will be given a score of 5 in the observation checklist. Field notes will be analyzed descriptively.

Table 1. Students' Observation Checklist

\begin{tabular}{|c|c|c|c|c|c|c|c|c|}
\hline \multirow{2}{*}{ No } & \multirow{2}{*}{ Activities } & \multirow{2}{*}{$\begin{array}{c}\text { Amount } \\
\text { of } \\
\text { Subjects }\end{array}$} & \multicolumn{5}{|c|}{ Valuation } & \multirow{2}{*}{$\begin{array}{l}\text { Total } \\
\text { Score }\end{array}$} \\
\hline & & & 1 & 2 & 3 & 4 & 5 & \\
\hline 1 & $\begin{array}{l}\text { Students pay attention to the researchers' } \\
\text { explanation. }\end{array}$ & & & & & & & \\
\hline 2 & Students follow the researchers' instructions. & & & & & & & \\
\hline 3 & $\begin{array}{l}\text { Students give opinions using expression and } \\
\text { hand gestures. }\end{array}$ & & & & & & & \\
\hline 4 & $\begin{array}{l}\text { Students give opinions with clarity and } \\
\text { appropriate statement. }\end{array}$ & & & & & & & \\
\hline 5 & $\begin{array}{l}\text { Students respond to another opinion and } \\
\text { question. }\end{array}$ & & & & & & & \\
\hline 6 & Students are eager to defend one's opinions. & & & & & & & \\
\hline 7 & Students' grammar and vocabulary in debating & & & & & & & \\
\hline 8 & Students have minimal reliance on the note. & & & & & & & \\
\hline 9 & Students' activeness in debating. & & & & & & & \\
\hline 10 & Students can summarize the result of the debate. & & & & & & & \\
\hline
\end{tabular}

Adapted from Rubiati, R (2010)

$$
\text { Score }=\frac{\text { Total Sore }}{\text { Moximal Sors }} \times 100
$$

Table 2. Description Of Checklist Valuation

\begin{tabular}{clc}
\hline Valuation & Categories & Rating \\
\hline 1 & Very Poor & $0-30$ \\
2 & Poor & $31-50$ \\
3 & Enough & $51-75$ \\
4 & Good & $76-85$ \\
5 & Very Good & $86-100$ \\
\hline
\end{tabular}

\section{FINDINGS}

In this section, the researchers describe and discuss the research results. Research findings are based on observation checklists and fieldnotes. The researchers describe the implementation of each stage of observation by applying classroom action research. This classroom action research is divided into three cycles. The results of three cycles can be explained as follows: 


\section{The First Cycle}

Table 3. Students' Observation Checklist In The First Cycle

\begin{tabular}{|c|c|c|c|c|c|c|c|c|}
\hline \multirow{2}{*}{ No } & \multirow{2}{*}{ Activities } & \multirow{2}{*}{$\mathrm{N}$} & \multicolumn{5}{|c|}{ Valuation } & \multirow{2}{*}{$\begin{array}{l}\text { Total } \\
\text { Score }\end{array}$} \\
\hline & & & 1 & 2 & 3 & 4 & 5 & \\
\hline 1 & Students pay attention to researchers' explanation & 60 & 8 & 36 & 14 & 2 & 0 & 130 \\
\hline 2 & Students obey to researchers' instruction & 60 & 0 & 24 & 35 & 1 & 0 & 157 \\
\hline 3 & Students give opinion by using expression $\&$ hand gestures & 60 & 18 & 22 & 17 & 3 & 0 & 125 \\
\hline 4 & Students give opinion with clarity and appropriate statement & 60 & 14 & 24 & 20 & 2 & 0 & 130 \\
\hline 5 & Students respond to another opinion \& question & 60 & 13 & 25 & 21 & 1 & 0 & 130 \\
\hline 6 & Students are eager to defend one's opinion & 60 & 5 & 27 & 25 & 3 & 0 & 146 \\
\hline 7 & Students' grammar and vocabulary in debating & 60 & 19 & 12 & 27 & 2 & 0 & 132 \\
\hline 8 & Students have minimal reliance on note & 60 & 28 & 16 & 13 & 3 & 0 & 111 \\
\hline 9 & Students' activeness in debating & 60 & 18 & 31 & 9 & 2 & 0 & 115 \\
\hline 10 & Students are able to summarize the result of debate & 60 & 29 & 14 & 16 & 1 & 0 & 109 \\
\hline
\end{tabular}

The score of the observation as follows:

$$
\text { Score }=\frac{1285}{3000} \times 100=42.83 \%
$$

Based on the observation list table above, it can be seen that $42.83 \%$ of the students' scores are involved and active in the debate. In the first cycle, the researchers observe students' activity in class while arguing. Based on the results of observations, most students paid attention to the researchers' explanation. Some students also join the class with enthusiasm.

\section{The Second Cycle}

Table 4. Students' Observation Checklist In The Second Cycle

\begin{tabular}{clccccccc}
\hline \multirow{2}{*}{ No Activities } & \multicolumn{1}{c}{ N } & \multicolumn{4}{c}{ Valuation } & Total \\
\cline { 4 - 7 } & & & 1 & 2 & 3 & 4 & 5 & Score \\
\hline 1 & Students pay attention to researchers' explanation & 60 & 2 & 12 & 35 & 8 & 3 & 178 \\
2 & Students obey to researchers' instruction & 60 & 0 & 7 & 23 & 24 & 6 & 209 \\
3 & Students give opinion by using expression \& hand gestures & 60 & 4 & 17 & 20 & 18 & 1 & 175 \\
4 & Students give opinion with clarity and appropriate statement & 60 & 0 & 14 & 37 & 7 & 2 & 177 \\
5 & Students respond to another opinion \& question & 60 & 5 & 12 & 29 & 13 & 1 & 173 \\
6 & Students are eager to defend one's opinion & 60 & 0 & 23 & 30 & 5 & 2 & 166 \\
7 & Students' grammar and vocabulary in debating & 60 & 3 & 13 & 31 & 10 & 3 & 177 \\
8 & Students have minimal reliance on note & 60 & 2 & 19 & 17 & 18 & 4 & 183 \\
9 & Students' activeness in debating & 60 & 5 & 21 & 22 & 8 & 4 & 165 \\
10 & Students are able to summarize the result of debate & 60 & 1 & 19 & 29 & 9 & 2 & 172 \\
\hline
\end{tabular}

TOTAL

1775

The score of the observation as follows:

Score $=\frac{1775}{3000} \times 100=59.17 \%$ 
Celtic: A Journal of Culture, English Language Teaching, Literature and Linguistics

Vol. 7, No. 2, December 2020.

E-ISSN: 2621-9158 P-ISSN:2356-0401

http://ejournal.umm.ac.id/index.php/celtic/index

Based on the observation checklist table above, it can be seen that there is an improvement in students' scores to pay attention and be enthusiastic about attending class. The teaching and learning process run well, and the students' activities in the debate were better than in the first cycle.

\section{The Third Cycle}

Table 5. Students' Observation Checklist In The Third Cycle

\begin{tabular}{|c|c|c|c|c|c|c|c|c|}
\hline \multirow{2}{*}{ No } & \multirow{2}{*}{ Activities } & \multirow{2}{*}{$\mathrm{N}$} & \multicolumn{5}{|c|}{ Valuation } & \multirow{2}{*}{$\begin{array}{l}\text { Total } \\
\text { Score }\end{array}$} \\
\hline & & & 1 & 2 & 3 & 4 & 5 & \\
\hline 1 & Students pay attention to researchers' explanation & 60 & 0 & 0 & 16 & 18 & 26 & 250 \\
\hline 2 & Students obey to researchers' instruction & 60 & 0 & 0 & 15 & 26 & 19 & 244 \\
\hline 3 & Students give opinion by using expression \& hand gestures & 60 & 0 & 0 & 8 & 27 & 25 & 257 \\
\hline 4 & Students give opinion with clarity and appropriate statement & 60 & 0 & 0 & 14 & 20 & 26 & 252 \\
\hline 5 & Students respond to another opinion \& question & 60 & 0 & 0 & 17 & 19 & 24 & 247 \\
\hline 6 & Students are eager to defend one's opinion & 60 & 0 & 0 & 6 & 16 & 38 & 272 \\
\hline 7 & Students' grammar and vocabulary in debating & 60 & 0 & 0 & 9 & 18 & 33 & 264 \\
\hline 8 & Students have minimal reliance on note & 60 & 0 & 0 & 13 & 25 & 22 & 249 \\
\hline 9 & Students' activeness in debating & 60 & 0 & 0 & 9 & 26 & 25 & 256 \\
\hline 10 & Students are able to summarize the result of debate & 60 & 0 & 0 & 11 & 14 & 35 & 264 \\
\hline
\end{tabular}

TOTAL

The score of the observation as follows:

Score $=\frac{2555}{3000} \times 100=85.17 \%$

Based on the third cycle observations, it can be concluded that the third cycle is the best compared to the other cycles. The majority of students are eager to defend one's opinion. They can summarize the result of the debate and paid attention to the researchers' explanation. The majority of students were enthusiastic about joining classes. All activities in the third cycle ran well and were reflected in their responses. The teaching and learning process runs well, and the students' speaking ability also shows an improvement. Most students can give opinions with good expressions. They can also respond to other groups' opinions spontaneously. They give their opinions when the debate (pros and cons) begins. Some students have minimal reliance on notes when giving and responding to the opinions of others. Some students can also respond to opinions clearly and accordingly - the students' activeness in arguing increases. Students actively provide opinions and respond to other opinions. Based on this research, the researcher found that all the indicators used as material for this study's observations had increased. It can be concluded that the debate technique can improve students' speaking ability once the last cycle was completed. 


\section{DISCUSSION}

From the research findings, it can be seen that the students' speaking ability had improved from cycle to cycle. From one cycle to another, it takes two weeks of learning to debate. The third cycle is the best. Students improve their speaking skills after being taught through debating techniques, which are applied for three cycles. Because on the third cycle of the debate, the whole meeting runs well. The students become more active and feel enthusiastic about giving their opinions and defending them. There is a significant improvement from cycle I to cycle III. These research findings are in line with the statement that debate is an appropriate technique to improve students' speaking skills (Arung, 2016). In conducting research, Fauzan (2016) said that debate improves the students' speaking score and increases the classroom atmosphere of teaching speaking.

The first cycle shows the percentage of students' assessment in the debate is $42.83 \%$. The lecturers apply debate techniques in teaching speaking. Many students enthusiastically attended classes, but some students did not pay attention and did not obey the given instructions. Many students were still confused about debating techniques because they had never practiced debating. Researchers found that many students were still confused about the debate procedure and their grammar and vocabulary were still low. Researchers also found that many students were still unable to give opinions by using expressions and hand movements well and were less able to respond to peers' opinions. Many students were unable to provide and respond to opinions accurately and used statements accordingly. The students felt shy and afraid of making mistakes. Many students still looked at notes or leaflets and found it challenging to summarize the debate.

In the second cycle, the percentage of students' activity is $59.17 \%$. It shows the teaching-learning process is better than before. Students can give their opinions and respond well to other opinions during the debate. They can use their expressions and hand movements to respond well and defend opinions. In this cycle, the students are more confident than before. They do not look as nervous or ashamed as in the first cycle but still cannot use the right and proper hand movements to respond to and defend opinions. However, some students still have bad grammar and vocabulary during the debate.

In the third cycle, the percentage of students' activity is $85.17 \%$. This result shows that the teaching-learning process is the best of the other cycles. Students become more confident to give their opinions during the debate. They use expressions and hand movements to give an accurate opinion, and they can respond to other opinions and defend their opinions appropriately. They do not see their notes to help them speak.

The debate technique cannot solve all students' problems in speaking. Still, through the debate technique, students become less afraid and more confident to express their opinions and improve their speaking performances. By applying this technique in the classroom, students who are usually passive learners during the teaching and learning process become active learners because they want to talk and argue with other students to defend their opinions. Through debate, students are enthusiastic about speaking in class because they want to show their ability to speak and debate. Students are encouraged to communicate during the debate, such as defending arguments and giving their opinions to their friends. They can also summarize the conclusions of the 
Celtic: A Journal of Culture, English Language Teaching, Literature and Linguistics

Vol. 7, No. 2, December 2020.

E-ISSN: 2621-9158 P-ISSN:2356-0401

http://ejournal.umm.ac.id/index.php/celtic/index

debate and to respond to other opinions. This study is in line with Baso (2016). There is a significant difference between students' speaking abilities before and after using debate techniques in the speaking process's accuracy.

The description above shows that the debate technique can improve students' speaking ability, especially on the ten indicators. The results of this study indicate that debate can significantly enhance speaking skills.

\section{CONCLUSION}

Based on the research findings, it can be concluded that students' speaking ability at semester III English Education College Students of 2019/2020, Universitas Potensi Utama, which consists of 60 students, was improved through the debate technique. The speaking ability of students in giving opinions was improved through debate techniques. In addition, the students' speaking ability in responding to other people's opinions improved significantly through the debating technique. This debate can positively attract almost all students to become active speakers in the classroom's teaching and learning process. Next, the grammar skill and vocabulary mastery of students have increased incisively during the period of debating. Finally, the role of the debate technique will be shared widely with lecturers on campus to improve students' speaking ability. Usually, debates are exciting to carry out in improving speaking skills. Students have many opportunities to practice speaking and be active involved in debates. As a result, they work cooperatively as a team and speak more actively in the classroom.

\section{Suggestions}

This study's findings can provide suggestions for improving teaching and learning activities, especially in teaching speaking. The suggestions of this study are defined as follows; Debate technique is useful for teaching speaking skills to college students because it involves a cognitive process in finding ideas and opinions that students can use to defend their opinions. Students are more active in participating in speaking in class. Therefore, the researchers recommend that lecturer can apply debate to guide their students in speaking in the class. In selecting topics, the researchers shall provide interesting topics for students to be more enthusiastic about giving their opinions. Researchers can reduce students' nervousness by involving them directly in speaking English through debate. The debate is also believed to positively influenced grammar skills and vocabulary mastery. The researchers also recommend the application of the debating technique to other researchers and lecturers.

\section{ACKNOWLEDGMENT}

Researchers would like to thank Kementrian Riset, Teknologi dan Pendidikan Tinggi Republik Indonesia (KEMENRISTEKDIKTI), especially Direktorat Riset dan Pengabdian Masyarakat - Direktorat Jenderal Penguatan Riset dan Pengembangan for funding this research.

\section{REFERENCES}

Aristy, I., Hadiansyah, R., \& Apsari, Y. (2019). Using Three Step-Interview to Improve Students' Speaking Ability. Project: Professional Journal of English Education, 2(2), 74-79. 
Arung, F. (2016). Improving the Students' Speaking Skill through Debate Technique. Journal of English Education, 1(1), 70-76.

Baso, F. A. (2016). The Implementation of Debate Technique to Improve Students' Ability in Speaking. Exposure Journal, 5(2), 154-173.

Fauzan, U. (2014). The Use of Improvisations Technique to Improve The Speaking Ability of EFL Students. Dinamika Ilmu, 14(2), 264-287.

Fauzan, U. (2016). Enhancing Speaking Ability of EFL Students through Debate and Peer Assessment. EFL Journal, 1(1), 49-57. http://dx.doi.org/10.21462/eflj.v1i1.8

Ghazali, A. S. (2013). Pembelajaran Keterampilan Berbahasa. Bandung, PT Refika Aditama

Harmer, J. (2007). The Practice of English Language Teaching. England: Pearson Education Limited.

Iman, J. N. (2017). Debate Instruction in EFL Classroom: Impacts on the Critical Thinking and Speaking Skill. International Journal of Instruction, 10(4), 87-108.

Iriantara, Y., \& Syaripuddin, U. (2013). Komunikasi Pendidikan. Cetakan Pertama. Bandung; PT Remaja Rosdakarya.

Iskandarwasid, (2008). Strategi Pembelajaran Bahasa. Bandung: Rosdakarya.

Junaida, R., \& Prastiyowati, S. (2018). Enhancing Students' Speaking Ability at $10^{\text {th }}$ Grade of Computer and Network Engineering Class at SMKN 4 Malang through L1/L2 Based Strategies. Celtic: A Journal of Culture, English Language Teaching, Literature, \& Linguistics, 3(1), 56-71. https://doi.org/10.22219/celtic.v3i1.7859

Krieger, D. (2005). Teaching Debate to ESL students: A six-class unit. The Internet TESL Journal, 11(2).

Kunandar. (2011). Langkah Mudah Penelitian Tindakan Kelas Sebagai Pengembangan Profesi Guru, Cetakan ke-VII. Jakarta: PT Raja Grafindo Persada.

Mafruudloh, N., \& Fitriati, R. (2020). The Effect of Project-Based Learning to the Students' Speaking Ability. Celtic: A Journal of Culture, English Language Teaching, Literature, \& Linguistics, 7(1), 57-64. https://doi.org/10.22219/celtic.v7i1.12203

Mulyani, I. S. (2018). Meningkatkan Kemampuan Berbicara dengan Metode Debat dalam Proses Pembelajaran Bahasa Inggris pada Peserta Didik Kelas VII C SMPN 4 Cianjur. Jurnal JOEPALLT Journal of English Pedagogy, Linguistics, Literature, and Teaching, 6(1), 1-10. DOI: https://doi.org/10.35194/jj.v6i1.255

Pradana, S. A. (2017). Using Debate to Enhance Students' Speaking Ability as Their Character Building. English Education: Jurnal Tadris Bahasa Inggris, 10(1), 149163.

Rubiati, R. (2010). Improving Students' Speaking Skill Through Debate Technique (A Classroom Action Research with First Semester Students of English Language Teaching Department Tarbiyah Faculty at IAIN Walisongo Semarang in the Academic Year of 2010/2011). Published Thesis. Semarang: Institut Agama Islam Negeri Walisongo.

Thornbury, S. (2005). How to Teach Speaking. USA: Longman Methodology.

Usman, A. H. (2015). Using the Think-Pair-Share Strategy to Improve Students' Speaking Ability at Stain Ternate. Journal of Education and Practice, 6(10), 3745 . 